Bulletin of Pharmaceutical Sciences
Assiut University
Website: http://bpsa.journals.ekb.eg/
e-mail: bullpharm@aun.edu.eg

\title{
CYTOTOXIC EFFECT OF DEFINE CONCENTRATION OF YARROW (ACHILLEA MILLEFOLIUM) EXTRACT USED IN IRANIAN TRADITIONAL MEDICINE ON AGS HUMAN GASTRIC CANCER CELL-LINE
}

\author{
Mohammad Mostakhdem Hashemi ${ }^{1}$, Nahid Poursharifi ${ }^{1}$, Fariba Kokabi ${ }^{1}$, Jale Yuzugulen ${ }^{2}$, \\ Majid Marjani $^{2^{*}}$ and Abdoljalal Marjani ${ }^{* *}$ \\ ${ }^{1}$ Metabolic Disorders Research Center, Department of Biochemistry and Biophysics, Golestan \\ University of Medical Sciences, Gorgan, Golestan Province, Iran \\ ${ }^{2}$ Faculty of Pharmacy, Eastern Mediterranean University, 99628, Famagusta, North Cyprus \\ via Mersin 10, Turkey
}

Gastric cancer is one of the main cancer-related death causes in the world threatening almost 12 million human lives by 2020. Achillea millefolium L. (yarrow) with domestic Iranian name of Bumadaran, has been as a curative plant for several medical conditions for a long time. Its antimicrobial and wound healing effects have been reported and in this study, we aimed to survey the in-vitro cytotoxic and anti-cancer effects of this plant. After taxonomically identification of Achillea millefolium L., its hydroalcoholic extract was extracted and the AGS gastric cancer and L-929 normal fibroblastic cell-lines with treated by the different concentrations of extract in 3 time periods (24, 48, and $72 \mathrm{hrs})$. MTT assay was performed for the evaluation of cytotoxic effects. The $24 \mathrm{hrs}$ treatment did not affect cell survival, notably, while the concentrations of 64 and $16 \mu \mathrm{g} / \mathrm{ml}$ were determined as $I C_{50}$ concentrations at 48 and $72 \mathrm{hrs}$ incubation times respectively. The $72 \mathrm{hrs}$ incubation time with $16 \mu \mathrm{g} / \mathrm{ml}$ showed the best effectiveness on cancerous cell-line while being safe for normal cell-line. The long-term treatment of AGS cancer cell-line by low concentrations of yarrow extract could be useful for the cytotoxicity upon this type of cancerous cells.

\section{INTRODUCTION}

Cancer is an almost widespread disease underlying many cases of disorders, deaths, and disabilities all around the world ${ }^{1}$. Many organs can be involved with this disorder with an interesting pattern related to gastrointestinal (GI) cancers worldwide. GI cancers are classified as gastric cancer (GC), pancreatic cancer (PC), colorectal cancer (CRC), esophageal cancer (EC), and hepatocellular carcinoma (HCC $)^{2}$. Among them, GC with the fourth position of common cancers and the second cause of cancer-related deaths worldwide is a main field of interest in health issues $^{3 \& 4}$. There is a tenfold variance in the incidence of Gastric cancer incidence rates through the world ${ }^{5}$ and geographically, Asia itself has almost two-thirds of all gastric cancer cases $^{6}$. In addition, this kind of cancer is the most common cancer and cancer-related death cause in Iranian society (first and the third position of common cancers in Iranian men and women respectively ${ }^{6}$ ) with almost 10000 incident cases and 8000 deaths each year ${ }^{7}$. According to the variable incidence of gastric cancer due to time trends, geographic variation, and the migration, it is suggested that the environmental and lifestyle factors are the major contributors to the etiology of this disease. These factors may include: Helicobacter pylori infection, Dietary factors,

Received in 2/2/2021 \& Accepted in 2/3/2021

*Corresponding author: Majid Marjani, E-mail: majidmarjani1379@gmail.com

*Corresponding author: Abdoljalal Marjani, E-mail: abdoljalal@yahoo.com 
Tobacco, obesity, and others ${ }^{8}$. There are controversial reports in the incidence trend of this cancer, so that despite a decrease in incidence and mortality due to the development strategies of diagnosis and treatment, the burden (incidence and mortality) are still high ${ }^{3}$ because of population aging and growth and the spreading of cancer-related lifestyles ${ }^{9}$. The global estimations predict 15 million cases and 12 million deaths by 2020 due to this cancer ${ }^{10}$. GC classification is mainly performed based on two aspects: the anatomic appearance and histological types of cancer which has cardiac/non-cardiac and enteric/non-enteric subtypes $^{11}$. Systemic chemotherapy remains the mainstay of medical care for different types of progressive gastric cancer, whereas uncertainty remains regarding the choice of the regimen ${ }^{12 \& 13}$. Many studies indicate multimodal therapy as the best appeal to treat progressive gastric cancer as a systemic disease ${ }^{14}$. Yarrow (Achillea millefolium L.) is a wild plant as a member of Asteraceae ${ }^{15}$ family with many subdivisions of species which are spread over a wide area around the world ${ }^{16}$. The apparent characteristics of these plants are typically hairy and aromatic leaves with flat clusters of small flowers at the end of their stem. Of course, some of these flowers are even grown as garden plants due to their different-colored flowers ${ }^{17 \& 18}$. The Achillea name is originated from the Achilles in the literary Trojan War of the Iliad in which yarrow was used to heal the soldiers' wounds. On the other hand, Bumadaran is a well-known name for several species of Achillea in Iranian language ${ }^{15}$. The geographical disturbance of its growth contains eastern, southern, central Europe and Asia ${ }^{19}$ and widely in different parts of Iran, mainly Azerbaijan, Eelam, Esfahan, Fars, and Loresatn provinces. The folkloric medicinal use of Yarrow involves the treatment of diverse diseases, including inflammation, hemorrhage, pneumonia, rheumatic pain and gastrointestinal disturbances due to the presence of their tonic, anti-inflammatory, anti-spasmodic, diaphoretic, diuretic and emmenagogic agents ${ }^{16 \& 20}$. Also, Achillea species are the most important indigenous economic plants of the Anatolia area so that the Turkish people traditionally drink herbal teas prepared from some Achillea species to alleviate the abdominal pain and flatulence ${ }^{21}$. Of course several studies have verified the effects of yarrow in the field of modern medicine. These studies have proven the antitumor ${ }^{22}$, liver protective $\mathrm{e}^{23}$, antioxidant, antimicrobial $^{24}$, anti-inflammatory ${ }^{25 \& 26}$, anti secretary, and gastro-protective activities ${ }^{27 \& 28}$ of this plant. In addition, there have been plenty of reports, introducing this plant as a bioactive component rich genus. Numerous fractions such as flavonoids, terpenoids, lignans, amino acid derivatives, fatty acids and the alkamides (nitrogen containing lipophilic components) have been discovered in this plant genus $^{29}$. The volatile oils of Achillea contain monoterpenes as the most representative metabolites and high levels of sesquiterpenes too $^{30 \& 31}$. The aerial parts of Achillea species include nitrogen-containing compounds of proline VIII, stachydrine IX, betonicine X, betaine XI and choline $\mathrm{XII}^{32 \& 33}$. Most of diarrhea-protective feature of Achillea is related to betaines, the components that contain permanent positive charge on the quaternary ammonium moiety ${ }^{34}$ with additional immunosuppressive activity in the experimental animals ${ }^{35 \& 36}$. Anti-proliferation is another bioactivity that is reported about the isolated constituents from Achillea falcata and Achillea clavennae. Four sesquiterpene lactones have been isolated from Achillea falcata, which had significant ability to inhibit $\mathrm{HaCaT}$ cell growth and identified as $3 \beta$ methoxy-iso-seco-tanapartholide XIII, tanaphillin XIV, iso-seco-tanapartholide XV, and 8-hydroxy-3-methoxy-iso-secotanaparatholide XVI. The deduction of Keratinocytes cell viability is mainly found because of the presence of these components 36. However, the most cytotoxic activity of these plants is attributed to a flavonol, centaureidin $\mathrm{XX}$, which was already known as cytotoxic agent ${ }^{37}$. Anyhow, there are still several unknown aspects of Achillea plants that need more attention ${ }^{15}$. Indeed, natural crude extracts and biologically active compounds from plant species used in traditional medicine may represent valuable sources for such new preservatives $^{38}$. To our knowledge there has not been any study targeting the direct cellular effect of Achillea millefolium $L$. extract on AGS cancer cell-line. Hence, this study was designed for the evaluation of cytotoxic effects of the crude extract of Achillea millefolium $L$. on the AGS human gastric cancer cell-line. 


\section{MATERIALS AND METHODS}

\section{Plant material}

Yarrow flowers (domestic and native name: Bumadaran) were purchased from a local apothecary shop in Gorgan, Iran. The voucher specimen of plant Achillea millefolium $L$. with herbarium No. 4001 was identified in Mazandaran University, Sari, Mazandaran, Iran and have been deposited in the Metabolic Disorders Research Center, Gorgan Faculty of Medicine, Golestan University of Medical Sciences. After taxonomic identification as the Achillea millefolium $L$., the hyroalcoholic extract of yarrow was prepared based on maceration method. For this aim, plant materials were left in fhade to be well-dried. Then, they were thoroughly powdered using an electric blender and $100 \mathrm{~g}$ of grounded plant material was placed in a $1000 \mathrm{ml}$ beaker. 500 $\mathrm{ml}$ of alcohol/distilled water (DW) solution (with the ratios of $70 \%$ and $30 \%$, respectively) was added to the dish and mixed properly followed by leaving at room temperature for 72 hours. After 72 hrs, the solvent was separated and the remained solution was filtered by Wathman filter paper $(0.2 \mu \mathrm{m})$. The yielded crude extract was then concentrated using rotary evaporator. Final Achillea millefolium L. extract was used to make a serial concentration used in this study.

\section{Sample preparation}

The residues of crude extract were suspended in dimethylsulfoxide (DMSO)/medium (1:9) and the dilutions of 1 ppm, 2 ppm, 4 ppm, 8 ppm, 16 ppm, 32 ppm, $64 \mathrm{ppm}$, and $128 \mathrm{ppm}$ were obtained. All of the mentioned serial concentrations were again centrifuged at $10000 \times \mathrm{g}$ for 5 minutes to eliminate any probable non-dissolved fractions.

\section{Cell-lines culture}

The gastric cancer cell-line AGS (as case cell-line) and mouse fibroblasts normal cellline (as the control normal cell-line) which were kind gifts from department of microbiology of Golestan university of medical sciences, were cultured in DMEM and RPMI1640 media (Bio-idea, IR Iran, lot numbers: BI1004 and BI-1007) respectively supplemented with heat-inactivated fetal bovine serum $(10 \%)$ (Bio-idea, IR Iran, lot number: BI-1201) 100 $\mathrm{U} / \mathrm{ml}$ penicillin, $100 \mu \mathrm{g} / \mathrm{ml}$ streptomycin (Bio- idea, IR Iran, lot number: BI-1203) and incubated under humidified environment at $37^{\circ} \mathrm{C}$ and $5 \% \mathrm{CO}_{2}$ as previously described ${ }^{39}$. The mycoplasma-free conditions of the celllines were proven with a Myco-Probe Mycoplasma Detection Kit (R\&D Systems, Minneapolis, MN).

\section{MTT assay}

The MTT assay was performed according to the previously described method ${ }^{40}$. In brief, cells were seeded in a 96-well plate at a concentration of $1 \times 10^{4}$ cells $/ \mathrm{ml}$. After $24 \mathrm{hrs}$ incubation at $37^{\circ} \mathrm{C}$, serial concentrations of Achillea millefolium $L$. extract $(1,2,4,8,16$, 32, 64, and $128 \mu \mathrm{g} / \mathrm{ml}$ ) and DMSO/medium (1:9) were added. Both AGS and L-929 cell lines were treated with these concentrations of plant extracts in triple (three wells for each concentration). The cells were incubated in a humidified atmosphere with $5 \% \mathrm{CO}_{2}$ in $37^{\circ} \mathrm{C}$ for three time intervals of 24, 48, and $72 \mathrm{hrs}$ in different plates. The medium was renewed every day. After a careful washing with PBS, $20 \mu 1$ MTT (3-(4,5-dimethylthiazol-2-yl)-2,5diphenyl tetrazolium bromide) (Sigma-Aldrich) solution with the concentration of $4.14 \mathrm{mg} / \mathrm{ml}$ was added to each well and incubated at $37^{\circ} \mathrm{C}$ for 4 hours. After removal of the medium, the formazan crystals were dissolved in DMSO and the optical density of each well was measured at $540 \mathrm{~nm}$ with a different wavelength of 630 nm using a plate reader (statfax 4300, chromate, USA). The $\mathrm{IC}_{50}$ value was calculated using nonlinear regression analysis and determination of growth inhibition was performed according to below formula:

Growth Inhibition $=($ Control OD - sample OD / Control OD)

\section{Statistics}

The results were analyzed using SPSS (version 16) software and unpaired samples ttest was used for estimations. The results are expressed as mean $\pm \mathrm{SD}$. The P-value $<0.05$ was considered as statistically meaningful in all analyzes.

\section{RESULTS AND DISCUSSION}

\section{Results}

In the current study, the cytotoxic effects of different concentrations of the Achillea millefolium $L$. extract were assessed on the 
AGS gastric cancer cell-line. The MTT assay was performed over 3 different incubation times of 24,48 , and 72 hrs. on the other hand; the safety of anti-cancer drug is another issue to be considered in addition to its cytotoxicity, so that the desired treatment should not have a notable cytotoxic effect on the normal cells. Hence, the same treatments of the target plant extract were done on L-929 normal fibroblast cell-line to evaluate its safety upon normal cells. As shown in figure $1 \mathrm{~A}$, the $24 \mathrm{hrs}$ incubation of cells did not reveal any significant difference about the cell survival in none of the treated concentrations (pvalue $>0.05$ ). The interesting fact about $24 \mathrm{hrs}$ period of treatment was the ineffectiveness of none of extract concentrations even the highest one $(128 \mu \mathrm{g} / \mathrm{ml})$ while in longer periods of incubation, the cytotoxic effects were clearly seen in even mild concentrations $(32 \mu \mathrm{g} / \mathrm{ml})$. Overall, the high survival of both cancerous and normal cells-lines demonstrated that $24 \mathrm{hrs}$ period of incubation with this extract could not reveal any meaningful effects on target cells (pvalue $>0.05$ ). But, by $48 \mathrm{~h}$ of drug treatment (figure 1B), the survival of cancer cells declined in concentrations of 16,32 , and 64 $\mu \mathrm{g} / \mathrm{ml}$ so that in the $64 \mu \mathrm{g} / \mathrm{ml}$ concentration, only $50 \%$ of cancer cells survive.
At this incubation time there was a step by step decline in AGS cell-line survival by the increase of extract concentrations, while the deduction of survival was very slight in the to the desired goal (cytotoxicity on cancer cellline and safety upon normal cells). Finally, we saw some interesting results regarding $72 \mathrm{hrs}$ (figure 1C) as the longest period of treatment.

The $\mathrm{IC}_{50}$ equal to $64 \mu \mathrm{g} / \mathrm{ml}$ was observed in $48 \mathrm{hrs}$ incubation time. In this concentration, normal fibroblast cells still had a higher survival $(69 \%)$ in comparison to that of cancer cells (50\%) and suggested that we were getting closer case of L-929 cell-line. The difference between survivals of these two cell-lines got greater so that we saw a notable difference in survival of two cells-lines about the concentration of $16 \mu \mathrm{g} / \mathrm{ml}$ which was considered as the $\mathrm{IC}_{50}$ of AGS cell-line with a survival of about $50 \%$. Nevertheless, the $85 \%$ survival of normal cells was seen in $16 \mu \mathrm{g} / \mathrm{ml}$ concentration of treatment and the difference between the survival of cancer and normal cells was statistically significant (p.value $<0.05$ ). Considering to this observation that the lowest cytotoxicity of normal cells is seen in $16 \mu \mathrm{g} / \mathrm{ml}$, it seems that the optimum, safe, and effective dosage of this extract could be set at $16 \mu \mathrm{g} / \mathrm{ml}$ (figure 2).
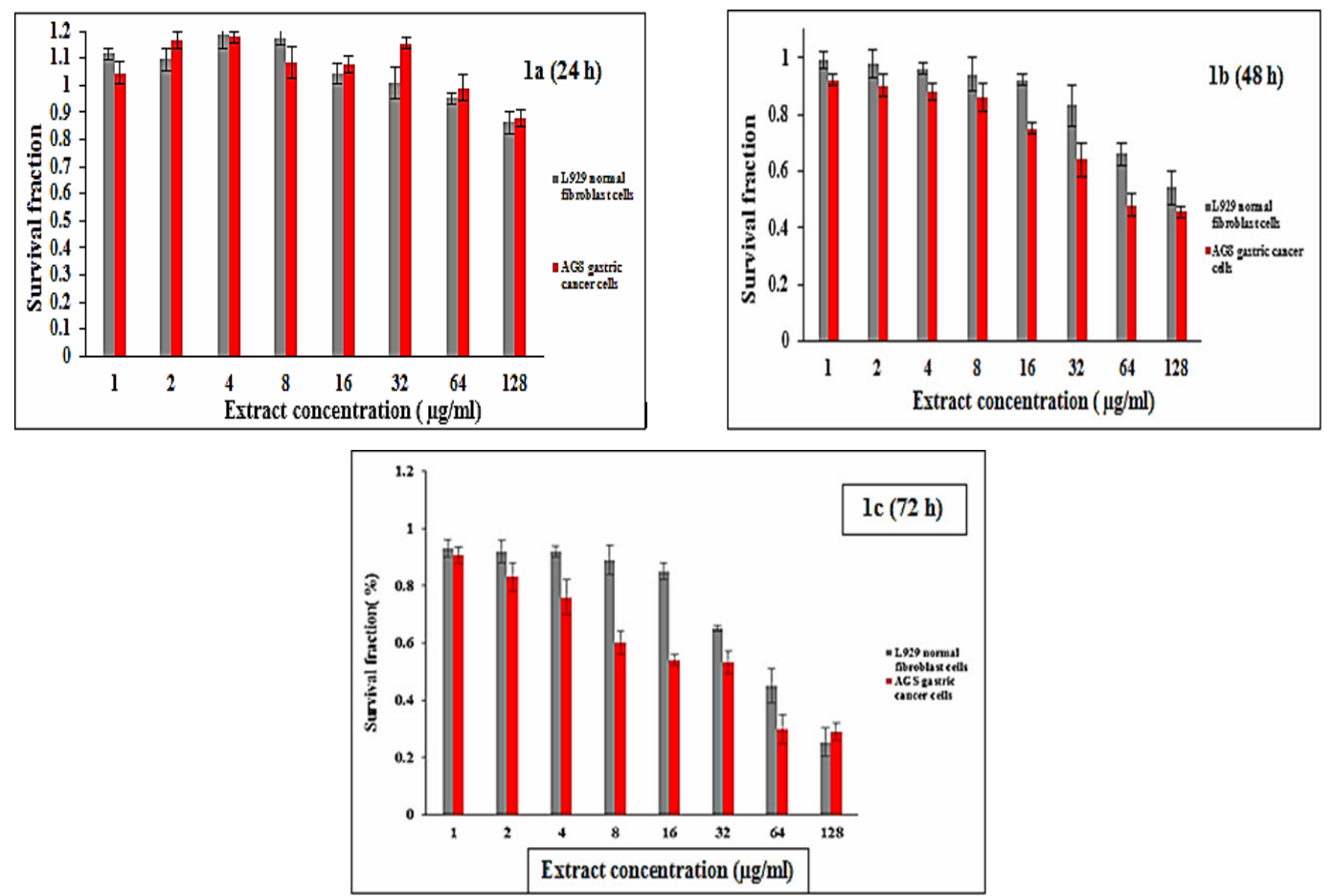

Fig. 1: The survival fraction of cancr and normal cell-lines in different concentrations and periods of treatment. 


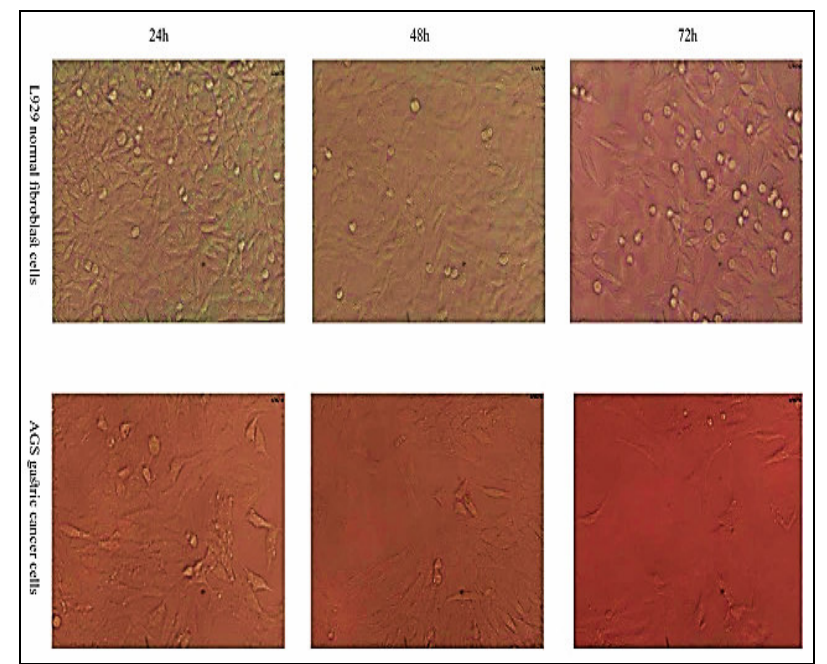

Fig. 2: The deductive trend of cell survival during 3 treatment days.

It is clearly seen that, however initial survival of the AGS gastric cancer cell-line (1.7) is higher than L-929 normal fibroblast cell-line (1.4), but it significantly decreases by the time so that at the end of day 3 , there is only 0.54 survived cancer cells while this portion is equal to 0.85 in case of normal cells.

\section{Discussion}

In the current study, the cytotoxic effects of Achillea millefolium $L$. hydroalcoholic extract were surveyed on the gastric cancer AGS and normal fibroblasts L-929 cell-lines. According to our observations, the concentration of 64 and $16 \mu \mathrm{g} / \mathrm{ml}$ had a proper inhibitory effect on the AGS gastric cancer cell-line in 48 and $72 \mathrm{hrs}$ treatment respectively. The $47 \%$ survival of AGS cancerous cells when treated with $64 \mu \mathrm{g} / \mathrm{ml}$ for $48 \mathrm{hrs}$ showed efficacy of this intervention, but it also affected L-929 normal cells (66\% survival) which alerts the insecurity of this approach for normal cells. On the other hand, the $72 \mathrm{hrs}$ treatment with $16 \mu \mathrm{g} / \mathrm{ml}$ had a slight cytotoxicity on normal fibroblasts cells $(85 \%$ survival) in comparison to acceptable cytotoxicity for cancer cells (50\% survival), the fact that convinced us to introduce this dose as an effective (for cancer cell-line) and safe (for normal cell-line) dose for the utilization in this type of studies. We thought that short periods of treatment could not show effective results even by high concentrations and at least there is a need for a $48 \mathrm{hrs}$ treatment period to the cytotoxic results to be appeared. Also, the $\mathrm{IC}_{50}$ $=64 \mu \mathrm{g} / \mathrm{ml}$ for $48 \mathrm{hrs}$ treatment is a field of conflict in our study. In the definition of this observation, it should be stated that, however this concentration showed a high cytotoxicity on cancer cells, but its same effect on normal cells, which reduced their survival by $66 \%$ limits its usage as a safe concentration. The other interesting observation took place in the case of the trend of survival deduction in different concentrations at $72 \mathrm{hr}$. we saw a steep slope in the reduction of cancer cells survival (from $90 \%$ to $54 \%$ ) by the increase of treatment concentration (from 1 to $16 \mu \mathrm{g} / \mathrm{ml}$ ), while this deduction was too slight for normal cells (from $90 \%$ to $85 \%$ ). But, the elevation of concentration from this point $(16 \mu \mathrm{g} / \mathrm{ml})$ intensely affects normal cells survival so that only a doubling of concentration from 16 to 32 $\mu \mathrm{g} / \mathrm{ml}$ results in a $20 \%$ decline (from $85 \%$ to $65 \%$ ) in L-929 cells survival which notifies the diverse effects of higher concentrations of Achillea millefolium $L$. extract in normal cells. This observation should be definitely considered in future studies and probable clinical utility of this extract. In the review of literature, Ghavame et al. $^{41}$ reported that $22.051 \mu \mathrm{g} / \mathrm{ml}$ concentration of the Achillea millefolium $L$. extract could reveal an $\mathrm{IC}_{50}$ effect against AGS gastric cancer cell-line. They used two different solutions for the herbal extract (DMSO and ethanol 50\%, respectively) and unfortunately did not report the final concentration of used stock. They reported that 
the substitution of extract solvent (DMSO against ethanol $50 \%$ with a considerably less cytotoxicity) did not alter the observed effects of AGS cell lines which confirms the cytotoxicity of Achillea millefolium L. extract per se. By the way the similarity of their effective concentration $(22.051 \mu \mathrm{g} / \mathrm{ml})$ and ours $(16 \mu \mathrm{g} / \mathrm{ml})$ is notable. Also, the selectivity of this extract on AGS cell line was reported by Ghavami et $a l .{ }^{41}$ So that they reported a significant lower cytotoxicity of mentioned extract in case of HFFF normal fibroblast cells. Csupor-Löffler attributed this cytotoxic activity of Achillea millefolium $L$. extract against cancerous cell-lines to the flavonol centaureidin which has less groups of $3^{\prime}$ hydroxy and 3-methoxy than its inactive analogue artemetin ${ }^{42}$. Casticin was reported as another cytotoxic agent through the inhibition of mitotic spindles synthesis and Bcl-2 depletion $^{43}$. paulitin and isopaulitin as two well-known sesquiterpenoid compositions with two $\alpha, \beta$-unsaturated systems have been reported as other candidates of yarrow extract cytotoxic effects ${ }^{44}$. Of course it should be considered that the higher concentrations of yarrow extract may reveal diverse effects in normal biologic systems especially germinating regions. According to a study by Montanari et $a l$. , the intraperitoneal and oral administration of the Achillea millefolium $L$. extract (with concentrations of 200 and $300 \mathrm{mg} / \mathrm{kg} / \mathrm{day}$, respectively) resulted in the alterations of spermatogenic action and reduction of germ epithelium ${ }^{45}$. Amirghofran et al. reported the $10 \mu \mathrm{g} / \mathrm{ml}$ concentration as the effective and cytotoxic concentration of Achillea millefolium $L$. in case of two cancer cells-lines while they did not see any considerable effect on HeLa cervix carcinoma cell-line ${ }^{46}$. The comparison of the results of our study and that of last mentioned study, suggests that the effectiveness of this extract may depend on the origin and nature of treated cells. The cytotoxicity of this plant against cancer cellline is so remarkable because of the genetically modification of these cells that harbor cDNAs encoding the proteins mediating common drug resistance activities such as mutation-activated epidermal growth factor receptor (EGFR) or which had knocked-out expression of tumor suppressor $\mathrm{p} 53^{47}$. AGS cell-line with predescribed MDR against anti-cancer agents such as epirubicin which possesses up-regulated ATP-binding cassette B1 (ABCB1) ${ }^{48}$ showed vulnerability against this extract which bolds the surprising results of current study even more. $\mathrm{ABCB} 1$ is a transporter protein with an effective activity for detoxifying in normal cells, but also its reverse activity against anticancer agents was reported during chemotherapy ${ }^{49850}$. We suppose that inhibition or at least down-regulation of ABCB1 mRNA expression is a possible mechanism for the efficacy of Achillea millefolium L. extract in AGS cell-line. Also, the decreased susceptibility to chemotherapy-induced apoptosis through the improvement of DNA integrity is suggested as another drugresistance mechanism ${ }^{51}$ and another probable mechanism which Achillea millefolium $L$. extract showed cytotoxicity could be attributed to this phenomenon that the mentioned extract may aggravate DNA fragmentation of AGS cells to induce their apoptosis death.

In concluding, we can claim that the low concentrations of the Achillea millefolium $L$. extract could have cytotoxic effects on gastric cancer cell-line while being safe for normal cells during longer treatment periods. Of course, it should be mentioned that the effectiveness of this extract may depend on the cancer type and cell origin and also it could act as a double-edged sword by affecting even normal cells in high concentrations.

\section{Funding statement}

This work was a grant supported by Deputy of Research of Golestan University of Medical Sciences (Grant No: IR.GOUMS.REC.1394.312) and Metabolic Disorders Research Center.

\section{Acknowledgement}

The authors present their deep thank to the Dr. Zahra Arab-bafrani for her valuable technical help.

\section{REFERENCES}

1. 1. J. Ferlay, I. Soerjomataram, R. Dikshit, S. Eser, C. Mathers, M. Rebelo, et $a l$., "Cancer incidence and mortality worldwide: sources, methods and major patterns in Globocan 2012", International 
Journal of Cancer, 136 (5), E359-E386 (2015).

2. M. A. Pourhoseingholi, M. Vahedi and A. R. Baghestani, "Burden of gastrointestinal cancer in Asia: An overview", Gastroenterology and Hepatology From Bed to Bench, 8 (1), 19-27 (2015).

3. E. Van Cutsem, X. Sagaert, B. Topal, K. Haustermans and H. Prenen, "Gastric cancer", The Lancet, 388 (10060), 26542664 (2016).

4. M. Abbasian, E. Mousavi, Z. Arab-Bafrani and A. Sahebkar. "The most reliable surface marker for the identification of colorectal cancer stem-like cells: A systematic review and meta-analysis", Journal of Cellular Physiology, 234 (6), 8192-8202 (2019).

5. B. W. Stewart and P. Kleihues, "World Cancer Report" (2003).

6. J. Ferlay, I. Soerjomataram, M. Ervik, R. Dikshit, S. Eser, C. Mathers, et al, "Cancer incidence and mortality worldwide": IARC CancerBase No. 11. Lyon, France: International Agency for Research on Cancer, GLOBOCAN 2012, International Journal of Cancer, 136 (5), E359-86 (2015).

7. S. Alireza, N. Mehdi, M. Ali, M. Alireza, M. Reza and D. Parkin, "Cancer occurrence in Iran in 2002, an international perspective", Asian Pacific Journal of Cancer Prevention, 6 (3), 359 (2005).

8. C. KD and N. AI, "Epidemiology of gastric cancer", World Journal of Gastroenterology: WJG, 12 (3), 354 (2006).

9. A. Jemal, F. Bray, M. M. Center, J. Ferlay, E. Ward and D. Forman, "Global cancer statistics" CA: A Cancer Journal for Clinicians, 61 (2), 69-90 (2011).

10. M. A. Han, K. S. Choi, H-Y. Lee, Y. Kim, J. K. Jun and E-C. Park, "Current status of thyroid cancer screening in Korea: Results from a nationwide interview survey", (2011).

11. J. Kim, "Protective effects of Asian dietary items on cancers-soy and ginseng", Asian Pacific Journal of Cancer Prevention, 9 (4), 543-548 (2008).

12. S. C. Park and H. J. Chun, "Chemotherapy for advanced gastric cancer: Review and update of current practices", Gut and Liver, 7 (4), 385 (2013).

13. J. Asadi and M. Mostakhdem Hashemi, "Valproic acid-Mediated reduction of DNA double-strand break reparation capacity of irradiated MCF-7 cells", Iranian Journal of Medical Physics, 13 (4), 289-295 (2016).

14. F. J. Fernández-Fernández and P. Sesma, "Gastric cancer", The Lancet, 374 (9701), 1594 (2009).

15. S. Saeidnia, A. Gohari, N. MokhberDezfuli and F. Kiuchi, "A review on phytochemistry and medicinal properties of the genus Achillea", DARU: Journal of Faculty of Pharmacy, Tehran University of Medical Sciences, 19 (3), 173 (2011).

16. A. Hemmati, A. Arzi, A. Adinehv, N. Mostofi, A. Mozaffari and A. Jalali, "Yarrow (Achillea millefolium L.) extract impairs the fibrogenic effect of bleomycin in rat lung", Journal of Medicinal Plants Research, 5 (10), 1843-1849 (2011).

17. M. Sheidai, N. Azanei and F. Attar, "New chromosome number and unreduced pollen formation in Achillea species (Asteraceae)", Acta Biologica Szegediensis, 53 (1), 39-43 (2009).

18. V. Mozaffarian, "A Dictionary of Iranian Plant Names", Tehran: Farhang Moaser Pub, Persian (1996).

19. W. C. Evans, "Trease and Evans' Pharmacognosy", E-book: Elsevier Health Sciences, (2009).

20. S. Saeidnia, A. R. Gohari, N. Yassa and A. Shafiee, "Composition of the volatile oil of Achillea conferta DC. from Iran", DARU Journal of Pharmaceutical Sciences, 13 (1), 34-36 (2005).

21. G. Honda, E. Yeşilada, M. Tabata, E. Sezik, T. Fujita, Y. Takeda, et al., "Traditional medicine in Turkey VI. Folk medicine in West Anatolia: Afyon, Kütahya, Denizli, Muğla, Aydin provinces", Journal of $\begin{array}{llll}\text { Ethnopharmacology, } 53 & \text { (2), } & \text { 75-87 }\end{array}$ (1996).

22. T. Tozyo, Y. Yoshimura, K. Sakurai, N. Uchida, Y. Takeda, H. Nakai, et al., "Novel antitumor sesquiterpenoids in Achillea millefolium", Chemical and 
Pharmaceutical Bulletin, 42 (5), 10961100 (1994).

23. L. T. Lin, L. T. Liu, L. C. Chiang and C. C. Lin, "In-vitro anti-hepatoma activity of fifteen natural medicines from Canada", Phytotherapy Research, 16 (5), 440-444 (2002).

24. F. Candan, M. Unlu, B. Tepe, D. Daferera, M. Polissiou, A. Sökmen, et al., "Antioxidant and antimicrobial activity of the essential oil and methanol extracts of Achillea millefolium subsp. millefolium Afan. (Asteraceae)", Journal of Ethnopharmacology, 87 (2-3), 215-220 (2003).

25. D. R. Burk, Z. A. Cichacz and S. M. Daskalova, "Aqueous extract of Achillea millefolium L. (Asteraceae) inflorescences suppresses lipopolysaccharide-induced inflammatory responses in RAW 264.7 murine macrophages", Journal of Medicinal Plants Research, 4 (3), 225234 (2010).

26. H. Tunon, C. Olavsdotter and L. Bohlin, "Evaluation of anti-inflammatory activity of some Swedish medicinal plants. Inhibition of prostaglandin biosynthesis and PAF-induced exocytosis", Journal of Ethnopharmacology, 48 (2), 61-76 (1995).

27. C. H. Baggio, C. S. Freitas, P. F. Nhaducue, L. Rieck and M. C. A. Marques, "Action of crude aqueous extract of leaves of Achillea millefolium $\mathrm{L}$. (Compositae) on gastrointestinal tract", Revista Brasileira de Farmacognosia, 12, 31-33 (2002).

28. A. M. Cavalcanti, C. H. Baggio, C. S. Freitas, L. Rieck, R. S. De Sousa, J. E. Da Silva-Santos, et al., "Safety and antiulcer efficacy studies of Achillea millefolium L. after chronic treatment in Wistar rats", Journal of Ethnopharmacology, 107 (2), 277-284 (2006).

29. X. T. Si, M. L. Zhang, Q. W. Shi and H. Kiyota, "Chemical constituents of the plants in the genus Achillea", Chemistry \& Biodiversity, 3 (11), 1163-1180 (2006).

30. F. Bakkali, S. Averbeck, D. Averbeck and M. Idaomar, "Biological effects of essential oils: A review", Food and Chemical Toxicology, 46 (2), 446-475 (2008).
31. E. Nemeth, "Essential oil composition of species in the genus Achillea", Journal of Essential Oil Research, 17 (5), 501-512 (2005).

32. M. Mehlführer, K. Troll, J. Jurenitsch, H. Auer and W. Kubelka, "Betaines and free proline within the Achillea millefolium group", Phytochemistry, 44 (6), 10671069 (1997).

33. S. Saeidnia and A. Gohari, "A search for betaine compounds within the Iranian Achillea", International Journal of Biology and Biotechnology (Pakistan), (2004).

34. K. V. Wood, C. C. Bonham, D. Miles, A. P. Rothwell, G. Peel, B. C. Wood, et al., "Characterization of betaines using electrospray MS/MS", Phytochemistry, 59 (7),759-765 (2002).

35. H. Hamidi, R. Jahanian and J. Pourreza, "Effect of dietary betaine on performance, immunocompetence and gut contents osmolarity of broilers challenged with a mixed coccidial infection", Asian Journal of Animal and Veterinary Advances, 5, 193-201 (2010).

36. F. Zhang, U. Warskulat and D. Häussinger, "Modulation of tumor necrosis factor- $\alpha$ release by anisoosmolarity and betaine in rat liver macrophages (Kupffer cells)", $\boldsymbol{F E B \boldsymbol { S }}$ Letters, 391 (3), 293-296 (1996).

37. S. Trifunović, V. Vajs, Z. Juranić, Ž. Žižak, V. Tešević, S. Macura, et al., "Cytotoxic constituents of Achillea clavennae from Montenegro", Phytochemistry, 67 (9), 887-893 (2006).

38. M. Al-Fatimi, M. Wurster, G. Schröder and U. Lindequist, "Antioxidant, antimicrobial and cytotoxic activities of selected medicinal plants from Yemen", Journal of Ethnopharmacology, 111 (3), 657-666 (2007).

39. C. Urueña, J. Mancipe, J. Hernandez, D. Castañeda, L. Pombo, A. Gomez, et al., "Gallotannin-rich Caesalpinia spinosa fraction decreases the primary tumor and factors associated with poor prognosis in a murine breast cancer model", BMC Complementary and Alternative Medicine, 13 (1), 74 (2013).

40. Z. Wang, J. Zhou, Y. Ju, H. Zhang, M. Liu and $\mathrm{X}$. Li, "Effects of two saponins 
extracted from the polygonatum Zanlanscianense pamp on the human leukemia (HL-60) cells", Biological and Pharmaceutical Bulletin, 24 (2), 159-162 (2001).

41. G. Ghavami, S. Sardari and M. A. Shokrgozar,"Anticancerous potentials of Achillea species against selected cell lines", Journal of Medicinal Plants Research, 4 (22), 2411-2417 (2010).

42. B. Csupor-Löffler, Z. Hajdú, I. Zupkó, B. Réthy, G. Falkay, P. Forgo, et al., "Antiproliferative effect of flavonoids and sesquiterpenoids from Achillea millefolium sl on cultured human tumour cell lines", Phytotherapy Research, 23 (5) 672-676 (2009).

43. J. A. Beutler, E. Hamel, A. J. Vlietinck, A. Haemers, P. Rajan, JN. Roitman, et al., "Structure-activity requirements for flavone cytotoxicity and binding to tubulin", Journal of Medicinal Chemistry, 41 (13), 2333-2338 (1998).

44. J. P. David, O. de, A. J. Santos, S. da, ML. Guedes, JM. David, H-B. Chai, J. M. Pezzuto, et al., "Sesquiterpene lactones from Ambrosia artemisiaefolia (Asteraceae)", Pharmaceutical Biology, 37 (2), 165-168 (1999).

45. T. Montanari, J. E. de Carvalho and H. Dolder, "Antispermatogenic effect of Achillea millefolium L. in mice", Contraception, 58 (5), 309-313 (1998).
46. Z. Amirghofran and M. Karimi, "Cytotoxic activity of Thymus vulgaris, Achillea millefolium and Thuja orientalis on different growing cell lines", Medical Journal of The Islamic Republic of Iran (MJIRI), 15 (3), 149-154 (2001).

47. V. Kuete, B. Wiench, M. S. Alsaid, M. A. Alyahya, A. G. Fankam, A. A. Shahat, et al., "Cytotoxicity, mode of action and antibacterial activities of selected Saudi Arabian medicinal plants", BMC Complementary and Alternative Medicine, 13 (1), 354 (2013).

48. A. V. Felipe, A. A. Moraes, J. de Oliveira, T. D. da Silva and N. M. Forones, "Establishment and partial characterization of an epirubicin-resistant gastric cancer cell line with upregulated ABCB1", Asian Pacific Jouronal of Cancer Prevention, 15, 6849-6853 (2014).

49. M. M. Gottesman, "Mechanisms of cancer drug resistance", Annual Review of Medicine, 53 (1), 615-627 (2002).

50. M. M. Gottesman, T. Fojo and S. E. Bates, "Multidrug resistance in Cancer: Role of ATP-dependent transporters", Nature Reviews Cancer, 2 (1), 48 (2002).

51. J. Plati, O. Bucur and R. Khosravi-Far, "Dysregulation of apoptotic signaling in cancer: Molecular mechanisms and therapeutic opportunities", Journal of Cellular Biochemistry, 104 (4), 11241149 (2008). 


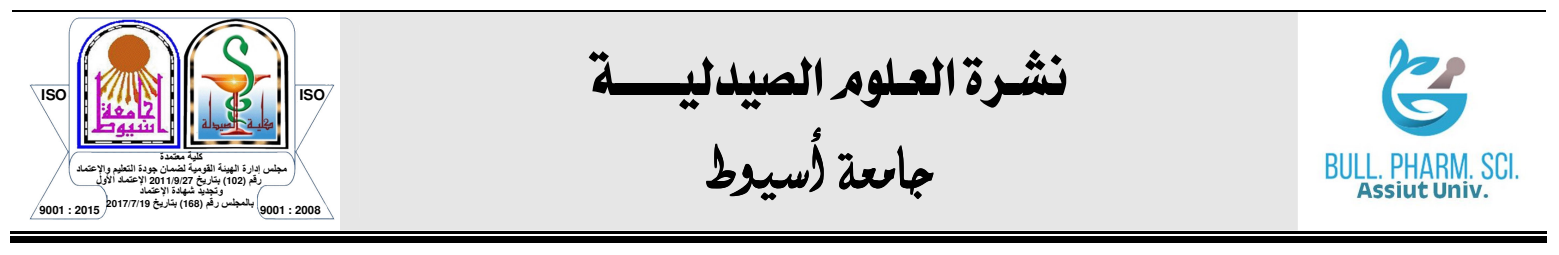

التأثير السام للخلايا من تركيز محدد من مستخلص القيصوم الألفي الأوراق (الحزنبل) المستخدم في الطب التقليدي الإيراني معند ملى خط خلايا سرطان المعدة البشري

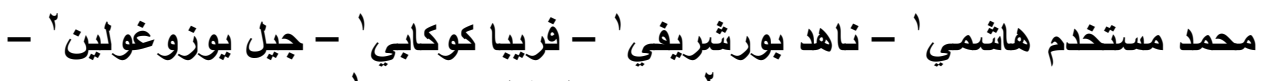

$$
\begin{aligned}
& \text { ماجل مرجاني' - عبد الجلال مرجاني' }
\end{aligned}
$$

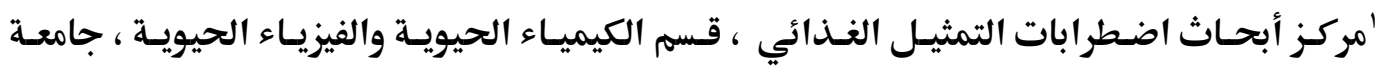

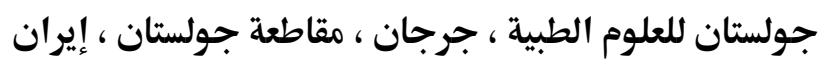

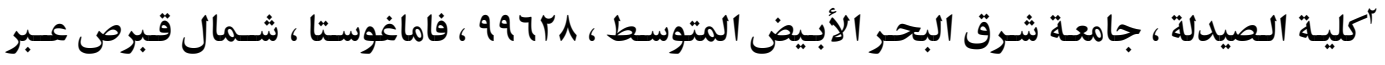

$$
\text { مرسين • • ، تركيا }
$$

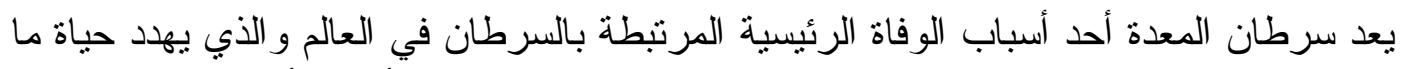

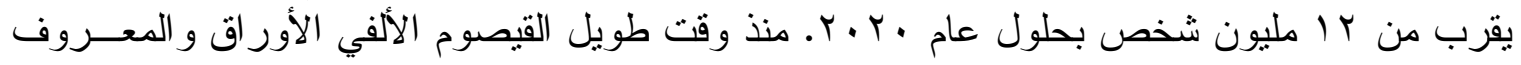

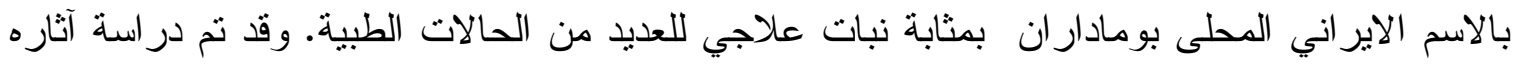

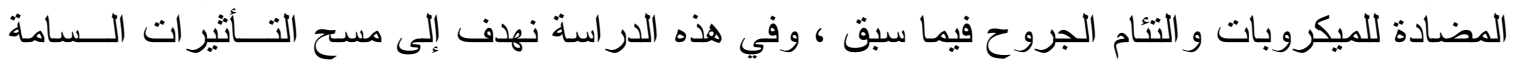

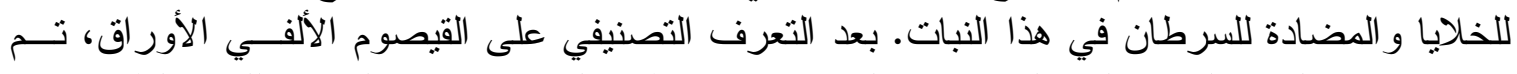

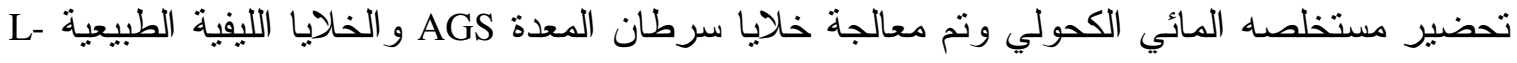

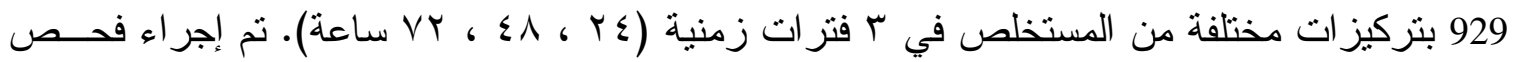

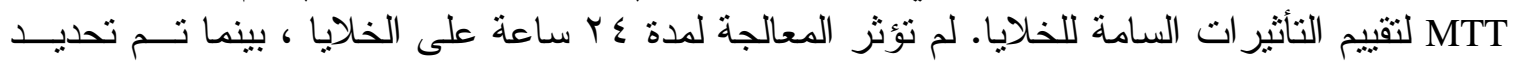

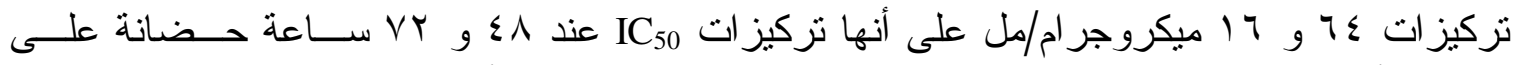

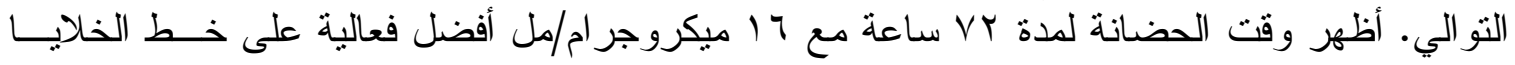

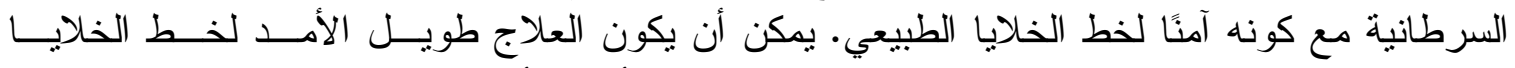

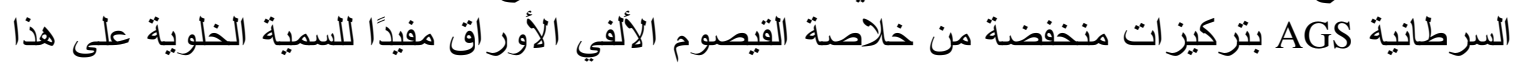
النوع من الخلايا السرطانية. 